\title{
POLÍTICAS PARA FRONTEIRA, HISTÓRIA E IDENTIDADE: A LUTA SIMBÓLICA NOS PROCESSOS DE DEMARCAÇÃO DE TERRAS INDÍGENAS TERENA*
}

Andrey Cordeiro Ferreira

Este artigo analisa a situação dos índios Terena no Mato Grosso do Sul, localizados em aldeias de uma região de fronteira internacional. A situação dos Terena e da fronteira difere de outras situações, especialmente da amazônica, ou mesmo da dos Guarani no próprio Mato Grosso do Sul. Os Terena não circulam entre fronteiras nacionais, não mantêm relações de trocas matrimoniais com grupos locais indígenas em outros países, não são portadores de identidades binacionais. Entretanto, a região que hoje ocupam foi o palco de uma das principais disputas territoriais das Américas e é uma área estratégica para a formação do Estado nacional brasileiro. E a história da definição da fronteira no então sul de Mato Grosso, bem como a da imobilização dos grupos étnicos e sociais nos séculos XIX e XX é fundamental para o entendimento da situação interétnica no Mato Grosso do Sul hoje.

Tal afirmação se confirma quando consideramos os conflitos decorrentes da judicialização de processos de identificação e demarcação de terras indígenas no estado do Mato Grosso do Sul. Nos processos judiciais movidos contra a identificação e a demarcação de terras indígenas terena são construídos discursos políticos que reativam formas de exclusão e rebaixamento simbólico-discursivo, nos quais a situação de fronteira aparece como operador central. Dos processos jurídicos emergem duas táticas discursivas que visam deslegitimar a reivindicação de terras ao anularem a tese da tradicionalidade da ocupação: a do questionamento da origem nacional dos índios Terena; o questionamento da sua autenticidade cultural e, consequentemente, da sua própria condição indígena.

Este artigo pretende então apresentar algumas reflexões teóricas sobre essas lutas simbólicas e também o processo de desenvolvimento da fronteira e seus efeitos sobre as sociedades indígenas. Pretendemos realizar dois movimentos analíticos: 1. a análise da luta simbólica que perpassa os processos 
judiciais desencadeados por conflitos territoriais entre os índios Terena e os produtores rurais, mostrando como a ideia de fronteira é ativada na construção de mecanismos políticos de exclusão e (des)legitimação de grupos étnicos; 2. a análise das políticas de Estado para a fronteira, as dinâmicas territoriais e sua confrontação com as políticas simbólicas indígenas nas diferentes situações locais na fronteira, que igualmente integram a luta simbólica por identidades reconhecidas como legítimas e territórios. Analisaremos como as formas de organização social indígena e a expressão simbólico-cultural produzem contradiscursos baseados na apropriação de símbolos e estratégias derivadas das diferentes políticas estatais para as fronteiras, criando novas formas de interpretação da sua própria identidade étnica.

A demarcação de fronteiras políticas estatais, no passado e hoje, de territórios indígenas supõe a definição de fronteiras identitárias, ou seja, o poder de traçar fronteiras territoriais supõe um ato concomitante de classificação e representação do que sejam os grupos sociais e suas fronteiras, nos quais se ampara em parte o próprio aspecto material da divisão. As "fronteiras", nos sentidos territorial, social e étnico, são construídas e desconstruídas em meio à luta de classificações. Essa luta de classificações se dá pela combinação de diferentes fatores históricos e culturais.

Um fator fundamental é o processo histórico de colonização e estatização dos territórios que exigiu a aplicação de diferentes políticas para a fronteira, inclusive políticas de assimilação e nacionalização dos povos indígenas. Outro fator é o da diversificação local dos efeitos das políticas nas diferentes sociedades indígenas, efeitos de apropriação, reinterpretação e ressignificação, fazendo com que a cultura e a identidade étnicas não sofressem processos unilaterais de mudança.

Buscaremos, a partir da análise de alguns tópicos (fronteira e luta de classificações, fronteira como laboratório de políticas de controle, fronteira e frentes de expansão econômica e fronteira e identidade), contribuir para a teorização do desenvolvimento histórico da fronteira, interpretação da história dos grupos indígenas nela localizados e análise dos conflitos atuais. Esse esforço pode auxiliar a pensar outras situações a partir de uma perspectiva histórica e processual, com base em alguns apontamentos teórico-históricos.

\section{Os sentidos da fronteira e a luta de classificações}

Analisaremos aqui algumas peças judiciais integrantes de lides que envolvem os índios Terena e os proprietários rurais, especialmente os índios 
das terras indígenas de Cachoeirinha, no município de Miranda; de Limão Verde, localizada no município de Aquidauana; e da terra indígena de Buriti, localizada no município de Dois Irmãos de Buriti. Nos três casos, processos de identificação e demarcação de terras foram iniciados com a constituição de Grupos de Trabalho de Identificação de 1997 a 2000, e tiveram como desdobramento ações judiciais (realizadas por pequenos e grandes proprietários de terras) que contestavam os processos administrativos de identificação e demarcação.

No caso dos índios de Buritis, a decisão do juiz federal acatou o argumento dos autores, alegando que as terras objeto da lide enquadravam-se nos critérios da súmula 650 do STF. Da decisão, houve apelação por parte da FUNAI, na qual se coloca com clareza o conteúdo e o objetivo da ação.

Os Autores, na presente ação declaratória, pleiteiam a antecipação parcial da tutela para verem declarada a nulidade ou ineficácia dos trabalhos realizados pela FUNAI, procedimento administrativo nas terras de suas propriedades, e tendo como objeto do pedido principal de que as terras de propriedade e posse dos Autores não são "terras tradicionalmente ocupadas pelos índios"; a declaração de nulidade de todos os trabalhos realizados pela FUNAI, nas áreas dos imóveis dos Autores, inclusive o levantamento antropológico; a inconstitucionalidade do Decreto $\mathrm{n}^{\circ}$ 1.775/96, por violação a letra do art. 231, caput e $\S \S$ $1^{\circ}$ e $2^{\circ}$, da Constituição Federal (Apelação de 11/11/2004, Ação Declaratória, Processo no 2001.60.00.003866-3).

Nos autos do processo consta a solicitação de produção de prova pericial. Nos quesitos formulados pelos autores apresentados aos peritos, constam alguns que esclarecem, de forma inequívoca, o conteúdo simbólico da estratégia jurídica:

5.1. Informe o sr. Perito onde viviam os índios Terena no período histórico anterior à data de 1797 ?

5.2. Informe o sr. Perito se, de acordo com a sua origem, os seus costumes, tradições, enfim, em relação à sua cultura, poderiam ser considerados como índios brasileiros?

5.4. Se em relação às informações contidas naqueles documentos poder-seia afirmar a imemorialidade ou ocupação tradicional daqueles índios nas terras da Serra ou Planalto de Maracajú, conforme a letra e o espírito do Art. 231 da Constituição Federal? (Perícia Antropológica, nos Autos do Processo, 2001.60.00.003866-3). 
Tal questionamento ressurge igualmente nos casos de Cachoeirinha e Limão Verde, em processos judiciais de diferentes naturezas. No caso da contestação da FUNAI a uma ação de reintegração de posse contra os índios de Cachoeirinha, ${ }^{1}$ fica claro também que o teor do argumento dos autores é similar ao do caso de Buritis:

A princípio coloca-se um aspecto de suma importância quanto aos descendentes dos Guaná-Txané, os Terena contemporâneos de não serem considerados índios brasileiros são provenientes do Chaco (Ação Reintegração de Posse, Processo $\mathrm{n}^{\mathrm{o}}$ 2005.60.00.010230-9).

A temática da origem nacional é igualmente acionada no caso dos índios de Limão Verde pelos advogados representantes das partes envolvidas no processo.

Sabendo-se que os índios Terena não são brasileiros, sendo originários do Chaco Paraguaio, e que eles vieram para o Brasil no século XVIII, onde se estabeleceram pela primeira vez? [...] Portanto, os índios Terena que reivindicam as terras particulares dos autores não são descendentes de índios brasileiros e sim de índios paraguaios, o que evidentemente lhes retira a condição de primitivos das regiões brasileiras, já que seus ancestrais com certeza absoluta estão no país vizinho, ou seja, no Paraguai, na região do Chaco Paraguaio, onde deveriam então reivindicar terras e jamais no Brasil de onde não são originários (Autos do Processo 968145-0).

Nessas contestações judiciais eram utilizados certos tipos de discursos político-jurídicos que afirmavam que os índios Terena "são originários do Paraguai", do lado "externo" da fronteira, e que a ocupação dos territórios da margem esquerda do rio Paraguai (hoje território brasileiro, correspondendo à região do Pantanal) não poderia ser enquadrada na categoria de tradicional exatamente por isto. ${ }^{2}$ Esta argumentação supõe toda uma analítica histórica e toda uma construção de categorias políticas e jurídicas que fundamentam a ação judicial.

Como podemos ver pelo extrato acima, o processo judicial se estabelece em dois patamares diferenciados: o da luta pelo território e o da luta pela representação legítima acerca das relações entre grupos sociais e territórios. A luta por interesses materiais é permeada por uma luta especificamente simbólica acerca da história dos grupos, de sua origem, da sua autenticidade enquanto grupo étnico, de maneira que se procura a dissolução da legitimidade do sujeito que representa a si mesmo como portador de uma história e de uma origem particular: as sociedades indígenas. Ao mesmo tempo, 
as representações indígenas, sob a forma de mito e ritual, também podem, como no caso terena, invocar meios especificamente simbólicos de criação de um contradiscurso que integra o próprio conflito de classificações. São estas duas dimensões que pretendemos explorar neste texto.

Do ponto de vista teórico, devemos indicar que as formas simbólicas são também expressão de relações de força tanto especificamente ideológicas, quanto materiais. E nesse sentido:

As lutas a respeito da identidade étnica ou regional, quer dizer, a respeito de propriedades (estigmas ou emblemas) ligadas à origem através do lugar de origem e dos sinais duradouros que lhes são correlativos, como o sotaque, são um caso particular da luta de classificações, lutas pelo monopólio de fazer ver e fazer crer, de dar a conhecer e de fazer reconhecer, de impor a divisão legítima do mundo social e, por esse meio, fazer e desfazer grupos (Bourdieu 1989:113).

Assim, a luta de classificações abrange a busca pelo poder de fixar a identidade legítima, e por extensão, o poder de traçar as fronteiras das identidades sociais e das suas bases materiais, entre as quais o próprio território. Como indica Bourdieu, a etimologia da palavra região (regio) conduz ao princípio da divisão e o ato de poder do regere fines, ato de traçar fronteiras, dividir o interior do exterior (Bourdieu 1989:114). O regere fines produz e é produto de um ato de poder, ou se quisermos ser mais diretos, acrescenta força simbólica que institucionaliza relações de força no plano das representações sociais como se derivassem não das relações de força, mas da própria natureza das coisas, reificando uma situação socialmente produzida como situação dada a priori. O poder de classificar é o poder de traçar fronteiras que fundem o real e uma determinada representação do real.

Nesse sentido, o processo de definição de identidades sociais e o processo político de definição de territórios não são somente análogos, mas em última instância derivados das mesmas estruturas de poder, já que:

O regionalismo (ou o nacionalismo) é apenas um caso particular de lutas propriamente simbólicas em que os agentes estão envolvidos quer individualmente e em estado de dispersão, quer coletivamente e em estado de organização, e em que está em jogo a conservação ou a transformação das relações de forças simbólicas e das vantagens correlativas, tanto econômicas como simbólicas [...] (Bourdieu 1989:124).

Assim, a "fronteira" - entendida como uma realidade política que se impõe às relações entre nações e povos com os territórios, ou como uma 
metáfora para a interpretação dos processos de definição de identidades sociais - remete ao mesmo tipo de processo: o poder de criar e legitimar classificações, definir limites entre o interior e o exterior. Chegamos aqui então ao elemento crucial do conflito e da judicialização dos processos de demarcação de terras indígenas. O discurso "nacionalista" que cria uma oposição entre "proprietários nacionais" x "índios estrangeiros ou paraguaios" é uma forma dessa luta simbólica. A fronteira nacional aparece como elemento de desqualificação do sujeito indígena dentro do processo. Entretanto, a desqualificação simbólica através da evocação da ideia de nacionalidade em contraposição à de etnicidade se liga mais especificamente ao problema dos títulos de propriedade e aos próprios fundamentos de legitimação da propriedade privada, como o direito de ocupação e o trabalho. A ideia de nacionalidade serve assim para atestar a anterioridade da ocupação privada em determinados territórios, ao passo que, supondo-se a origem externa dos índios, colocam-se duas ordens de problemas: 1. onde os índios estavam antes de estarem dentro das fronteiras nacionais?; 2. como e por que os índios chegaram a se localizar nos territórios que atualmente ocupam?

A luta de classificações envolve não somente a luta pela representação legítima da "origem" e da "identidade social", mas também o poder de conservação ou transformação de seções locais de uma estrutura agrária. Ao mesmo tempo, estão em jogo as próprias classificações e a estrutura simbólico-cognitiva que amparou parcial e às vezes contraditoriamente as políticas e os processos que fizeram com que a estrutura agrária se definisse de uma determinada maneira na fronteira. Ou seja, a luta de classificações não é somente um invólucro para um conflito econômico ou de interesse material, mas é uma luta pelo poder legítimo de impor representações, pela manutenção ou destruição das representações hegemônicas ou dominantes que em si mesmas expressam forças e acrescentam força simbólica e, por isso, material aos sujeitos que as produzem e por elas são produzidos. Daí a busca por uma identidade que seja definida no âmbito do Estado nacional para se utilizar como critério de legitimação, pois assim se retira o próprio poder de classificação dos grupos e se coloca esse poder nas mãos do Estado. $\mathrm{O}$ "nacionalismo" é uma estratégia ou um dispositivo simbólico acionado para a conservação de certa correlação de forças e uma distribuição específica de terras em uma estrutura agrária, que em si mesma não pode ser compreendida sem o entendimento do significado da fronteira dentro da sociedade nacional.

Devemos então caracterizar com clareza a situação da fronteira aqui abordada para podermos apontar todas as demais questões, teóricas e políticas, associadas a ela. A fronteira pode primeiramente ser entendida como o resultado de um ato político que delimita linhas de divisão territorial. Mas 
a fronteira ainda tem outro sentido, sociológico, empregado como operador descritivo de realidades sociais nas quais a dimensão territorial ocupa um lugar central. A fronteira não é apenas uma linha demarcatória que divide um território e marca os limites da soberania de um Estado nacional, mas é também, e principalmente, o objeto de relações e dinâmicas sociais que a definem e a redefinem continuamente. Devemos então, desde já, indicar que o conceito político-jurídico de fronteira expressa apenas uma dimensão ou um uso possível, aos quais podemos adicionar outros, como os de fronteira agrícola, extrativista etc. Estes diferentes sentidos da ideia de fronteira, longe de serem excludentes, na realidade entrelaçam-se.

Iremos aqui entender a fronteira como tipo particular de organização social do espaço em que prevalece o conflito pelo poder de definir o espaço, que pode ser diferenciada em fronteira aberta e fechada. A fronteira aberta pode ser definida então como "um espaço não-estruturado/espaço em incorporação ao espaço global fragmentado", em que "a apropriação da terra é realizada em escala e ritmos crescentes, contudo não é total, nem uniforme, nem irreversível" (Becker 1990:16-17). Além disso, é possível assumir que na região de fronteira aberta "coexistem formas de organização da produção diversificadas" (Idem, ibidem).

O conceito de fronteira é, desta forma, uma ferramenta teórica que delimita uma região concreta, abrangendo territórios em integração, pouco povoados em relação às sociedades nacionais, cuja população local apresenta diferenças culturais e de organização da produção (Léna \& Oliveira 1991:9). Nesse sentido sociológico mais abrangente, a fronteira é o espaço das políticas e dos processos de colonialismo interno que colocam em colisão grupos etnicamente diferenciados. ${ }^{3}$ A fronteira se diferencia assim da "frente de expansão", que é um objeto empírico envolvendo tipos de atividade, a combinação concreta de forças produtivas e relações de produção que se introduz em uma área de fronteira (Idem, ibidem).

As características socioespaciais acima indicadas permitem perceber a fronteira como uma região caracterizada pela instabilidade das relações entre grupos sociais e territórios, pela multiplicidade de formas de apropriação, estruturação e utilização dos territórios e dos recursos produtivos. Outro elemento importantíssimo diz respeito às relações de trabalho:

A hipótese alternativa é a de que a fronteira se organiza com o trabalho móvel, isto é, com trabalhadores assalariados — temporários e permanentes - e com pequenos produtores que vendem sua força de trabalho empregando-se em atividades rurais ou urbanas. A formação desse mercado de trabalho implica um processo de migração e mobilidade dominantemente induzido (Becker 1990:19). 
A fronteira é uma região em que vigora um tipo particular de organização social do espaço, no qual o colonialismo interno é um operador central, e em que existem diferentes formas de apropriação e uso do território e, consequentemente, das representações sobre o território e a identidade social. Ao mesmo tempo, na fronteira, são colocadas variadas formas e demandas relativas à exploração do trabalho. A mobilidade da força de trabalho é um elemento importante ao qual retornaremos mais adiante. Por outro lado, o fechamento da fronteira implica uma estruturação das relações espaciais e sociais, no estabelecimento de um padrão dominante de relação dos grupos sociais com os territórios e os espaços.

A ideia de fronteira tem assim uma tríplice significação: a fronteira política como limite entre unidades territoriais, a fronteira social ou identitária entre grupos, a fronteira econômica como espaço em incorporação ao mercado e relações de produção dominantes. Os três sentidos encontram-se, no caso aqui considerado, profundamente entrelaçados.

Podemos afirmar que o Mato Grosso do Sul constitui uma região de fronteira fechada, diferente de outras regiões de fronteira aberta, quando considerada a fronteira em seu sentido econômico. O Pantanal, local em que estão se desenrolando os conflitos territoriais, encontra-se, por outro lado, numa região de fronteira política entre Estados.

Nos conflitos acima mencionados são usados discursos classificatórios que constituem mecanismos para a definição das fronteiras das identidades dos grupos sociais e étnicos. Assim, o conteúdo da definição de fronteira não se restringe ao elemento nominalista da linha demarcatória de uma fronteira político-jurídica, mas indica sociologicamente as diferentes possibilidades de integração dos territórios e dos recursos naturais nas lutas e nos processos sociais e simbólicos.

Isto significa que os territórios que hoje são objeto dos conflitos judiciais foram integrados por meio de processos de colonialismo interno. As demarcações das terras indígenas, no plano da ação estatal, e outros processos de territorialização, como as ações de retomada/ocupações de terras, no plano das ações indígenas, visam questionar aspectos localizados da estrutura agrária produzida pela evolução da fronteira até seu fechamento. Essa estrutura agrária foi constituída também sobre diferentes representações acerca do índio e de seu lugar, entendido como espaço originário e como posição adequada. A busca da redefinição dos limites de terras indígenas, com o questionamento dos limites territoriais historicamente construídos, é efeito e desdobramento do processo de estruturação do espaço e de sua integração no ordenamento político, sendo questionadas também as representações acerca do lugar do índio. 
O enquadramento da região do Mato Grosso do Sul numa categoria de fronteira fechada nos obriga então à análise histórica do processo de transformação do espaço não-estruturado em espaço estruturado/integrado àquele nacional-estatal e ao sistema mundial, e a outros processos correlatos, como o desenvolvimento e a expansão do capitalismo na agricultura, envolvendo formas de organização do trabalho e produção, territorialização, mudança cultural. Nesses processos de integração/estruturação é que foram definidas as relações atuais dos grupos sociais e dos grupos indígenas com o território, ou seja, os que criaram as bases sociais (estrutura agrária, relações de poder) do atual conflito social e da luta de classificações.

\section{A fronteira como laboratório de políticas de controle}

Os índios Terena ocuparam durante o século XIX a principal região de fronteira do Brasil - a região Sul do então estado do Mato Grosso — na forma de territórios que faziam limite com o Paraguai. Tais territórios foram objeto de um complexo processo de colonização, que envolveu agências coloniais espanholas e portuguesas e inúmeras sociedades indígenas. Os processos de conquista colonial e a formação do Estado nacional definiram-se na segunda metade do século XIX, quando depois da Guerra do Paraguai o Estado nacional brasileiro conseguiu traçar as fronteiras nacionais apropriando-se definitivamente dos territórios de diversos povos indígenas, que foram fragmentados e submetidos a um processo de gestão estatal, eliminando-se a ameaça potencial representada pela República do Paraguai.

Essa situação específica da fronteira fazia com que a localização e a organização social dos povos indígenas fossem vistas como um problema de Estado. Como podemos ver no relato abaixo, do militar responsável pelo forte de Miranda:

Estes casamentos também servem de obstáculo para um aldeamento constante; porque muitos são contrahidos em outras diversas e distantes tribus, casandose muitas vezes os de Albuquerque e Miranda uns com os outros, e com os Cadiuéos, e ainda em outras toldarias vizinhas dos hespanhoes, das quaes vem igualmente homens e mulheres ligar com primeiros semelhantes allianças, que ordinariamente são de pouca dura; e como os maridos, sempre se mudam para a morada da mulher, praticando o mesmo os chamados captiveiros, tanto por semelhante motivo como por seguirem, e só por affecto, a seus senhores, resulta d'esta vaga pratica um inconstante circulo de mudanças que em nenhuma parte fixa o centro de sua residência. [...] 
Como este capitulo sobre a estabilidade d'estes Indios é talvez o mais fundamental para desvanecer a esperança de se aldearem elles de tal forma que sejam úteis a mineração, agricultura e população portugeza, eu devo ser mais extenso em relatar alguns fatos constantes e recentes (Ricardo Freire de Almeida Serra, "Continuação do Parecer sobre os índios Uaicurus e Guanás", 1803).

A ameaça externa ou a disputa territorial com outros Estados pelos territórios do sul de Mato Grosso, combinada com as características sociais da fronteira (baixa densidade demográfica, instabilidade da ocupação, que poderia ser eventual ou cíclica), fazia com que as características da organização social indígena fossem tratadas como problemas de Estado. No caso mais específico, os índios Guaicuru e Guaná possuíam certos traços que foram objeto de diferentes políticas de Estado. De maneira geral, podemos falar de três grandes problemas associados às sociedades indígenas, no diagnóstico realizado pelos poderes de Estado: 1. a mobilidade espacial, uma vez que a organização social dos índios supunha deslocamentos periódicos através de grandes parcelas de terras, matrimônios com grupos locais em grandes distâncias, inclusive atravessando fronteiras nacionais; 2 . a mistura e a segmentação, já que o sistema político era marcado pela existência de inúmeros líderes políticos e que, por conta das trocas matrimoniais e da prática da captura, existia uma grande mistura étnica dentro das próprias sociedades indígenas, especialmente entre os Guaicuru e os Guaná; 3. a alteridade étnico-cultural, levando-se em conta que existia uma grande recusa dos índios de serem assimilados às práticas de trabalho e produção impostas pela economia colonial.

Assim, a política de Estado no período entre 1790 e 1850 foi marcada pelo esforço de criar aldeamentos que cumprissem múltiplos objetivos: 1. quebrar a aliança entre os Guaicuru e os Guaná, enfraquecendo o poder militar dos primeiros, acabando com a mistura entre esses índios; 2 . criar uma linha de defesa do território brasileiro contra os espanhóis e depois os paraguaios, de maneira que os aldeamentos oficiais servissem como uma espécie de sustentáculos sociais das fortificações militares das regiões e do exército; 3. determinar de forma mais precisa os limites dos grupos indígenas, separando-os das antigas relações que mantinham, e criando as bases para uma fusão dos índios na massa da população. Assim, antes de o Estado incentivar a mistura e a mobilidade na fronteira, ele buscou erradicar certos tipos de mobilidade e mistura.

Essas políticas levaram a uma fixação de núcleos de ocupação indígenas nas regiões estratégicas do ponto de vista geopolítico. As regiões de Albuquerque, atual Corumbá e Miranda, foram os principais pontos de ocu- 
pação. Os índios Terena e os demais subgrupos Guaná foram incentivados pelo Estado a ocupar essas regiões no final do século XVIII. Essa região de fronteira, designada pelos portugueses de Pantanaes, sobrepunha-se a uma parcela dos territórios denominados pelos espanhóis de Chaco. Os índios terena designam a mesma região com o termo Exiwa. ${ }^{4}$

A ideia da origem paraguaia dos índios Terena parte então do pressuposto de que eles teriam vindo dos "territórios paraguaios" para o "território brasileiro" somente no século XVIII, entretanto, esse território ainda não havia sido definido e reconhecido como brasileiro, ao contrário, era objeto de disputa e luta com espanhóis. A fixação de índios em certas localizações estratégicas em que hoje se encontram alguns dos principais municípios da região foi fruto de uma política de Estado que visava exatamente, através da ocupação por índios aliados, assegurar e defender a fronteira. A ocupação indígena na região remonta ao século XVI, e a presença terena se fazia pelas relações de comércio na região do Itatins, próxima a Santiago de Xerez, localizada onde hoje está a cidade de Aquidauana. ${ }^{5} \mathrm{~A}$ região fora conquistada pelos Guaicuru e os Guaná no mesmo período. ${ }^{6} \mathrm{O}$ suposto "deslocamento ou migração terena para o território brasileiro" foi apenas um movimento de deslocamento populacional dentre outros tantos que ocorriam em um território que era de ocupação Guaná/Guaicuru. Era um deslocamento dentro de territórios de ocupação indígena e espanhola, como os próprios documentos do Exército brasileiro atestam. ${ }^{7}$

A definição dos territórios da região Sul de Mato Grosso como brasileiros ocorreria somente depois da Guerra do Paraguai, e só aconteceu, em grande medida, por conta da mobilização eficaz das sociedades indígenas da região pelo Estado nacional. Os territórios hoje brasileiros, e que são representados como brasileiros imemorialmente nos conflitos judiciais, foram na verdade assegurados há cerca de 140 anos atrás. Antes disso, eram territórios com uma tríplice reivindicação: indígena, espanhola e portuguesa. Alguns documentos mostram como esse processo é complexo e como a fronteira que separava o Brasil do Paraguai e que se sobrepôs a diversos territórios indígenas deslocou-se continuamente até alcançar seus limites atuais. Toda a região onde hoje se desencadeiam conflitos por conta da demarcação de terras indígenas foi também ocupada por espanhóis entre os séculos XVI e XVII, sendo sempre objeto de disputa com os índios.

Outra política seria materializada no "Regulamento acerca das Missões de Catechese e Civilização dos Índios — decreto no 426 de 24/07/1845". Este instrumento legal visava criar um tipo de intervenção política e uma organização do trabalho de civilização/gestão dos índios. Essa tentativa inscrevia-se nas condições políticas específicas da fronteira no Mato Grosso, o que obrigou as 
agências estatais e mesmo certos colonos e militares a uma política de gestão dos índios baseada em concessões aos interesses indígenas.

$\mathrm{O}$ artigo $1^{\mathrm{O}}$ tem 33 parágrafos que definem as atribuições da Diretoria de Índios. O $1^{\circ}$ estabelece como tarefa o exame do estado das aldeias estabelecidas. O $2^{\circ}$, dos recursos que oferecem para a lavoura; o $3^{\circ}$, o poder de "remoção" dos índios das terras, recomendando-se métodos brandos. O parágrafo $10^{\circ}$ estabelece o poder de redistribuir os "objetos" que forem destinados aos índios. O parágrafo $11^{\circ}$, a "demarcação" de terras que forem dadas aos índios. O parágrafo $12^{\circ}$, a fixação de terras para "plantação" dentro das aldeias e aquelas destinadas a arrendamentos. O parágrafo 16 indica que os comerciantes poderiam ter acesso às aldeias de forma "volante ou fixa". O parágrafo 19, "empregar os meios lícitos e brandos para atrair os índios às aldeias e promover casamentos entre eles e pessoas de outras raças". O $28^{\circ}$ aponta a vigilância sobre o contrato de trabalho para evitar o trabalho forçado. $\mathrm{O} 30^{\circ}$, o controle estrito de produção e renda das aldeias. $\mathrm{O} 32^{\circ}$ institui o diretor como "procurador" dos índios perante a justiça e as demais autoridades. O Diretor de aldeia distribui os "objetos" aos índios e fiscaliza suas plantações e lavoura. Comanda a força militar a serviço da aldeia. O parágrafo 13 do art. $2^{\circ}$ possibilita o alistamento militar dos índios. $\mathrm{O}$ artigo $6^{\circ}$ trata dos missionários e coloca-os com a responsabilidade de trabalharem os índios errantes.

$\mathrm{O}$ "regulamento das missões" de 1845 tem em si alguns dos elementos que seriam retomados no século XX pelo regime tutelar; os dispositivos de poder são relativamente similares, mas existem algumas diferenças importantes. Em primeiro lugar, o regulamento incentiva a mistura dos índios com outras raças, uma política de miscigenação dirigida, e nisso difere dos aldeamentos do século XX, nos quais se estabelecia uma política de separação racial. Ele também introduz a preocupação com a "demarcação de terras", a lavoura, a "regulação do trabalho indígena" e da renda das aldeias, bem como a atribuição do papel de "procurador dos índios" ao Diretor. Nesse sentido, é perceptível certa continuidade com a figura da tutela do século XX. Entre os anos de 1851 e 1860, se fariam os primeiros esforços de edificação de aldeamentos, no sentido estatal do termo, de acordo com o regulamento. Eles seriam construídos nas freguesias de Alburquerque e Miranda:

De um relatório, que me foi apresentado pelo digno Director Geral com data de 28 de abril próximo passado, extrahi as seguintes informações:

A causa que em primeiro lugar se deve apontar d'entre as que concorrem para que não se tirar proveito possível da catechese é a insufficiencia das sommas consignadas para as despezas que ela exige [...] mal chegão para satisfação das necessidades das Aldeas do Bom Conselho e de Miranda, não se podendo 
por tanto emprehender novos aldeamentos de tribus que se mostrão dispostas a relacionarem-se comnosco, nem ao menos a distribuir alguns brindes a todos os índios, que os vem procurar nesta capital.

Havendo-se esgotado aquella primeira verba, forçoso foi mandar suspender as obras das Capellas, Olarias em construção nas duas referidas aldeas, assim como os vencimentos dos mestres de musica, oleiro e alfaiate, que bastante falta tem feito, especialmente à do Bom Conselho, onde já se nota algum desenvolvimento intellectual nos índios Kinikináos, de que se compõe. [...] Estes Índios, de excellente índole, já prestão a sociedade diversos serviços, como camaradas das fazendas de cultura e criação, e como remadores das canoas empregadas na navegação entre os portos do Baixo Paraguai e desta capital; a aldea possue uma soffrivel banda de musica, e os indios menores, alem de acharem-se adiantados nas primeiras letras, vão aprendendo os ofícios de alfaiate, ferreiro, oleiro. A aldea de Miranda, mandada fundar pelo governo da Província em abril de 1860 sob a direcção do incansável Missionário Frei Mariano de Bagnaia, que muitos serviços tem aqui prestado a catechese, acha-se em embrião pelo motivo já declarado.

Grande é o numero de Índios que para alli forão attrahidos pelo mesmo Missionário, e nas visinhanças da Villa existe ainda dispersa uma não pequena porção, que elle empenha-se em incorporar na Aldea, cuja prosperidade muito deve interessar a todo o município, porque os Terena, Laianas, que nella habitão, não só prestão-se aos mesmos trabalhos que os da do Bom Conselho, mas ainda abastecem a Villa de gêneros alimentícios que cultivão (Relatório 1862:117-118).

As aldeias de Bom Conselho (Quiniquináu) e Miranda (Terena e Laiana) são assim as primeiras aldeias da Província de Mato Grosso, entendendo-se a aldeia como uma unidade territorial e administrativa criada pelo Estado para localizar os índios. Fica claro que, em contraposição à aldeia, o documento apresenta os índios dispersos nas vizinhanças da Villa, que correspondem às comunidades locais indígenas que escapavam da gestão estatal. $\mathrm{O}$ empreendimento de catequese e civilização dos índios ${ }^{8}$ desenvolve-se então no período imediatamente anterior à Guerra do Paraguai. Em 1860, em Miranda, é criado o segundo aldeamento da província.

É interessante notar que no ano de 1858 foi criada a repartição de terras públicas (decreto 2092 de 30/01/1858), em obediência à Lei de Terras de 1850, que começa a funcionar a partir do ano seguinte. Isto significa que um processo de medição de terras e definição de propriedades, ou seja, de controle fundiário, estava sendo estabelecido ou, pelo menos, almejado. No mesmo ano, o presidente da Província afirma: “Em Miranda muito conviria fazer hum aldeamento regular e disso encarreguei ao Commandante das Armas. Porem ter elle encontrado embaraços, para os quaes muito concorre 
a falta de hum sacerdote que exclusivamente se preste attrahir os índios de hum modo benévolo e insinuante" (Relatório da Província de Mato Grosso 1859:36). Quer dizer, a multiplicação dos aldeamentos se dá paralelamente ao dos mecanismos de controle da terra. No ano seguinte, seria iniciada a construção da aldeia de Miranda.

Entre 1800 e 1860, a composição social e demográfica da província se altera em traços significativos. E isto afetará profundamente a dinâmica social e marcará o processo histórico posterior. Vejamos os dados abaixo:

\section{Quadro 1 - População da Província de Mato Grosso - 1862}

\begin{tabular}{|l|l|}
\hline \multicolumn{2}{|c|}{ Condição } \\
\hline Livres & 30.846 \\
\hline Escravos & 7.052 \\
\hline Indígenas & 10 a $15 \mathrm{mil}$ \\
\hline Total & 52.538 \\
\hline
\end{tabular}

Os dados acima indicam que a população da província cresceu em termos gerais cerca de $20 \%$, mas o número de escravos diminuiu em torno de $30 \%$, enquanto o da população livre aumentou $50 \%$ em relação ao ano de $1850 .{ }^{9}$ Os dados relativos aos índios são apresentados à parte e não discriminados por freguesia, mas apontam no mínimo para uma estabilidade, já que o número de indígenas em 1849 estava entre 15 e 20 mil pessoas.

Ao mesmo tempo, o então presidente da Província nota o seguinte:

O que se pode afirmar por ser visível e incontestável é que a Capital Villa Maria, Villa de Sant'anna do Paranahyba e a Povoação de Albuquerque, hoje mais conhecida pelo nome de Corumbá, são os lugares da província que nestes últimos tempos mais tem crescido em população e commercio [...] (Relatório da Província de Mato Grosso 1862:36).

É no Valle do Paraguay que reside quase toda a população civilisada desta Província. Mais de 4/5 ocupão, em redor da Capital, um espaço de, quando muito, 1600 legoas quadradas, na parte superior oriental do dito Valle, limitado a Oeste pelo mesmo rio Paraguay, a Leste pelo São Lourenço, e atravessado pelo Cuyabá; e 1/10 pelo menos da referida população habita as freguesias de Albuquerque e Miranda, ribeirinhas, aquella do grande rio, e esta do seo tributário, o rio Miranda (Relatório da Província de Mato Grosso 1862:65-66). 
Com isto queremos chamar a atenção para o fato de que no período os aldeamentos se expandem, mesmo que modestamente; são estabelecidos os Diretores de Índios para administrar e controlar tais aldeamentos; há um aumento demográfico na província e, ainda especialmente, na região do Pantanal, ${ }^{10}$ onde estavam localizados então os Guaná e os Terena.

Assim, a fronteira como uma região de conflito, de luta pela apropriação e definição do espaço e dos territórios, era também uma zona de experimentação de políticas de dominação. Foram testadas políticas de aliança e colaboração ostensiva dos aparelhos de Estado, especialmente do Exército, com as sociedades indígenas, como estratégia de segurança e defesa do Estado nacional. Existia, nesse período, pouca preocupação com a definição interna dos limites do território. O principal problema de Estado era a disputa com outros Estados. Os problemas geopolíticos de manutenção dos territórios eram mais urgentes que os problemas de exploração econômica desses mesmos territórios. O Estado tolerava certas práticas culturais e precisava da aliança militar com as sociedades indígenas. E, ainda, a configuração da fronteira que não tinha sido sujeita à atuação sistemática das frentes de expansão possibilitava que os índios ocupassem efetivamente uma ampla faixa territorial em diferentes pontos do sul de Mato Grosso. Nesse sentido, havia um espaço para a tolerância relativa diante da diversidade étnicocultural e certa margem de concessão aos interesses indígenas.

A defesa do território, como objetivo estratégico do Estado, obrigava a utilização dos índios como força de apoio. Ao mesmo tempo, à medida que a região da fronteira passava por um crescimento demográfico e estabeleciam-se as frentes de expansão, a antiga mobilidade dos índios Guaicuru e Guaná e a profunda "mistura" que existia entre as sociedades indígenas eram alvo de políticas de controle e disciplinarização. A mistura e a mobilidade na fronteira, que seriam objetivos da política de Estado para os índios, só seriam aceitas se fossem uma mobilidade subordinada ao mercado e uma mistura direcionada para a assimilação. Não se podia aceitar, do ponto de vista da razão de Estado, a mistura interétnica entre sociedades indígenas e a mobilidade espacial autônoma. Certos agentes de Estado entendiam que a identidade cultural dos índios da região era tão sólida que seria difícil conseguir fundi-los na massa da população algum dia. ${ }^{11}$ A mistura entre grupos indígenas, a alteridade cultural e a mobilidade espacial resultante de diferentes modos de organização social e relações de produção eram entraves ao colonialismo.

Assim, a ideia de uma origem exclusiva em um ponto único do espaço localizado no Chaco e fora da fronteira nacional, presente nos conflitos judiciais, contrasta com a ocupação e a circulação dinâmica dos índios entre 
múltiplos pontos do território (nos que hoje são brasileiros e nos que hoje são paraguaios), em diferentes momentos históricos, e com a circulação dos próprios territórios (inclusive daquele que hoje é parte do Pantanal) em diferentes unidades políticas e espaciais, em diferentes lados da fronteira e, por isso, de posse de diferentes nações (incluindo-se aí as sociedades indígenas como nações). Os territórios e as fronteiras eram distintos, e o que hoje é território brasileiro era território sob disputa ou território paraguaio ou indígena, e o que hoje é visto como Pantanal fazia parte do Chaco.

A fronteira, mesmo sendo alvo de políticas experimentais de controle, não viu a consolidação desse controle sobre os grupos étnicos até a guerra do Paraguai. No entanro, os aldeamentos criados como parte das políticas de localização, separação e centralização lançariam bases importantes para o período pós-guerra. Isto porque apontavam para uma nova forma de incorporação dos espaços/territórios pela sociedade nacional, em que a terra, enquanto fator de produção, seria uma mercadoria e um bem extremamente disputados. Essas políticas preparavam o terreno para a atuação das frentes de expansão e a incorporação definitiva das terras à estrutura agrária.

\section{As frentes de expansão econômica, o fechamento da fronteira e as regiões de exceção}

A fronteira do sul de Mato Grosso, no sentido da fronteira política entre Estados, só foi definida após 1870, com a derrota do Paraguai na guerra. A instabilidade da fronteira e sua mobilidade (uma vez que as linhas demarcatórias não eram aceitas ou reconhecidas como definitivas) criavam uma situação em que a mobilidade espacial dos grupos étnicos e sua alteridade étnico-cultural eram vistas como problemas de Estado. Foi somente quando foram assegurados os limites territoriais da fronteira nacional que se desencadeou um processo de atuação sistemática das frentes de expansão econômica, e criaram-se as condições para a imobilização dos grupos étnicos e a criação de uma força de trabalho móvel, mas de antemão subordinada ao Estado.

A atuação dessas frentes de expansão, especialmente de uma frente agropastoril, possibilitou a estruturação do espaço e a incorporação definitiva das terras da região Sul de Mato Grosso ao espaço nacional. Essa incorporação condicionou ao mesmo tempo a forma da estrutura agrária regional e o lugar das terras indígenas dentro dela. A grande questão é saber quando se deu definitivamente o início da ação sistemática das frentes de expansão e quando se deu o fechamento da fronteira. Segundo Otávio Velho, um dos 
indicadores da atuação das frentes de expansão é o crescimento demográfico acelerado que, mesmo não sendo um elemento definidor, pode denunciar a existência das frentes de expansão (Velho 1972:12).

Os dados abaixo mostram a evolução demográfica da província e depois do estado do Mato Grosso.

Quadro 2 - População de Mato Grosso, 1872-1930

\begin{tabular}{|c|c|c|c|c|}
\hline $\mathbf{1 8 7 2}$ & $\mathbf{1 8 9 0}$ & $\mathbf{1 9 0 0}$ & $\mathbf{1 9 2 0}$ & $\mathbf{1 9 3 0}$ \\
\hline 60.417 & 92.827 & 118.025 & 246.612 & 349.857 \\
\hline
\end{tabular}

Nos vinte anos que se seguem à Guerra do Paraguai, a população total do Mato Grosso cresce cerca de 130\% se comparada com o ano de 1850. Nestes números não é considerada a população indígena. Nesse processo de crescimento demográfico, insere-se a política de incentivo à imigração de europeus: de 1872 a 1890 são 5.896; de 1890 a 1900, 3.445; de 1900 a 1920, 15.864; de 1920 a 1940, 47.002. A dinâmica demográfica acompanha a dinamização econômica e social. Significa a expansão da força de trabalho disponível na província, causa considerada fator de "seu atraso" em todo o século XIX. ${ }^{12}$ "Desse modo, o fim da guerra do Paraguai em 1870 marcou o início de uma fase de ampla abertura da economia de Mato Grosso ao exterior via comércio e navegação pelo rio Paraguai"13 (Borges 2001:31).

É importante também considerar a fixação no Mato Grosso de grande contingente de militares (especialmente oficiais), ex-combatentes da Guerra do Paraguai. Esses militares se tornariam fazendeiros e empresários na região, sendo então parte da nascente burguesia rural e empresarial do Estado. ${ }^{14}$ Temos então a configuração clara de um conflito ou choque sociocultural: os colonos, imigrantes estrangeiros ou nacionais vindos de outras regiões com os povos indígenas autóctones.

Uma nova fase de colonização se daria: agora poderíamos falar especificamente de um tipo de colonialismo interno, quando novos colonos iriam ocupar os territórios da província de Mato Grosso, no pós-guerra, especialmente no período 1870-1900. Aqui é o momento de formação de um Mercado Capitalista, que se desenvolve sob a forma de capitalismo monopolista, subsidiado pelo Estado. Logo, a "economia" ganha a força e a autonomia que no período anterior não tivera.

De forma geral, podemos indicar a constituição de duas grandes frentes de expansão: a frente extrativista e a frente agropastoril. As atividades extrativistas conheceram um grande boom no final do século XIX, enquanto as atividades 
agropecuárias tiveram um desenvolvimento menor, porém mais constante. Entre 1898 e 1914, a produção e as exportações de "erva-mate" e "borracha" responderam por mais de $80 \%$ do valor dos principais produtos exportados, posição que, em conjunto, mantêm até 1911, depois que o elemento dinâmico da economia passou a ser a agropecuária (Borges 2001:44-48).

A produção de erva-mate se inicia em 1882, quando Tomás Laranjeira consegue o direito de exploração entre o rincão do Júlio e o Iguatemi (sul do sul de Mato Grosso). Esta atividade seria consolidada com a formação da Companhia Mate Laranjeira, que exerceria o monopólio do setor. A Mate-Laranjeira se tornaria uma peça fundamental da estrutura de poder no Mato Grosso. ${ }^{15}$ Juntamente com a erva-mate, a borracha seria um produto importante na economia matogrossense. Ela foi extraída nas regiões dos rios Paraguai, Jurena, Arinos e Paranatinga e Alto Tapajós (após 1910, a crise da borracha brasileira freou seu desenvolvimento). Assim, a atividade extrativista conheceu um período de grande importância no início do século XX.

As principais atividades econômicas estavam concentradas sobretudo no extremo sul do Mato Grosso. A erva-mate e a borracha foram plantadas exatamente nesta região. O desenvolvimento da agropecuária se tornaria fundamental, nesta situação histórica, para a construção de um novo modo de distribuição do poder, que alteraria completamente a vida dos Terena. A agropecuária já estava sendo praticada enquanto atividade econômica importante desde 1850. ${ }^{16}$ No período pós-Guerra do Paraguai esta importância aumentaria: “[...] durante o exercício de 1878 a 1879 começou a apresentar uma importância significativa, fundamentalmente quando se observa que as exportações de gado vacum, carne seca, chifres e crinas conseguiram atingir um valor [...] correspondente a mais da metade das exportações realizadas" (Borges 2001:76).

Em 1915 o Mato Grosso tinha o $4^{\circ}$ maior rebanho bovino do Brasil, com 2.690.454 cabeças. Os principais municípios com criações eram: 1. Campo Grande; 2. Ponta Porã; 3. Bela Vista; 4. Corumbá; 5. Coxim; 6. Aquidauana; 7. Três Lagoas; 8. Miranda. Ou seja, a região do Pantanal foi uma região de grande concentração de atividade agropecuária, tendência que se iniciou logo após a Guerra do Paraguai. A agropecuária, apesar de configurar a terceira atividade em importância durante os anos iniciais da Primeira República, demonstrou ser a mais constante e, depois dos anos 1920, assumiu lugar de destaque. Também neste ramo estariam atuando as grandes empresas, especialmente multinacionais, das quais uma das mais importantes foi a Miranda Estância - The Miranda Estância Company — que controlava 219.056 hectares em Miranda (Borges 2001:79). 
Quadro 3 - Propriedades/Estabelecimentos Rurais no Mato Grosso - 1895

\begin{tabular}{|l|c|c|l|}
\hline \multirow{2}{*}{ Municípios } & $\begin{array}{c}\text { Número de } \\
\text { estabelecimentos }\end{array}$ & $\begin{array}{c}\text { Área ocupada } \\
\text { em hectares }\end{array}$ & \multicolumn{1}{c|}{$\begin{array}{c}\text { Atividades } \\
\text { produtivas }\end{array}$} \\
\cline { 2 - 4 } & 24 & 86.400 & Indústria pastoril \\
\cline { 2 - 4 } & 30 & 117.917 & Lavoura \\
\hline \multirow{2}{*}{$\begin{array}{l}\text { S. Luiz de } \\
\text { Cárcares }\end{array}$} & 254 & 84.650 & Indústria extrativa \\
\cline { 2 - 4 } & 136 & 952.272 & Indústria pastoril \\
\hline Corumbá & 4 & 154.088 & Lavoura \\
\hline Miranda & 91 & 1.818 .181 & Indústria pastoril \\
\hline Nioac & 187 & 2.631 .237 & Indústria pastoril \\
\hline
\end{tabular}

É possível notar pelo quadro acima que a "indústria pastoril" (é a expressão da época para designar atividades da agropecuária e seus produtos beneficiados) é a única com dados para a maioria dos municípios. Destaca-se ainda que o município de Miranda era o segundo maior em concentração de terras e posses no que se refere a esta atividade. A vila de Miranda era exatamente o local em que, em caráter principal, os Terena estavam localizados, lembrando que os territórios do município de Aquidauana eram parte da Vila de Miranda no século XIX.

Podemos visualizar claramente que as frentes de expansão da sociedade nacional atuam especialmente depois de 1870. O desenvolvimento de uma frente agropastoril na região do Pantanal aumenta exponencialmente a demanda por terras. O processo de delimitação e demarcação destas últimas é tardio. Mesmo no final do século XIX, o número de estabelecimentos regularizados era extremamente reduzido, com grande parte deles estando na condição de posses. ${ }^{17}$

Entre o início do processo de atuação sistemática das frentes de expansão e o "fechamento da fronteira" na região do Pantanal, temos um período de cerca de 60 anos. Nesse intervalo de tempo se dão os processos de incorporação de terras e de espaços à estrutura agrária da sociedade nacional, com uma nova forma de regulação de acesso, posse e propriedade da terra. A antiga instabi- 
lidade característica do período anterior à Guerra do Paraguai foi substituída por uma normatização rígida dos padrões de acesso e permanência na terra, predominando o mecanismo de mercado de compra e venda. Logo depois de iniciado esse processo de regularização das posses (cerca de dez anos após), deu-se também o processo de demarcação e construção das reservas de terras indígenas terena. Durante o século XX, a intervenção do Estado, através do SPI, especialmente na região Sul do Mato Grosso, estabeleceu processos de territorialização e mudança social dirigida que fixaram os índios Terena em "reservas". O quadro abaixo mostra de forma sintética o processo de constituição das reservas indígenas por parte do SPI.

\section{Quadro 4 - Processo de Formação das Reservas Indígenas Terena - Século XX}

\begin{tabular}{|l|c|c|}
\hline Reservas Indígenas & Área em hectares & Data do Decreto \\
\hline Cachoeirinha & 2.260 & 1904 \\
\hline Bananal-Ipegue & 6.337 & 1904 \\
\hline Lalima & 3.600 & 1905 \\
\hline Francisco Horta & 3.600 & 1917 \\
\hline Capitão Vitorino & 2.800 & 1922 \\
\hline Moreira-Passarinho & 171 & 1925 \\
\hline Buriti & 2.000 & 1928 \\
\hline Limão Verde & 2.500 & $(?)$ \\
\hline
\end{tabular}

Muitas dessas demarcações foram resultantes de decretos das esferas federais, estaduais ou municipais, dando margem a questionamentos tanto por parte dos índios, quanto dos proprietários, de maneira que a demarcação das terras não implicou sua efetividade ou a aceitação dos seus limites.

A partir do momento em que começa a atuação das frentes de expansão da sociedade nacional, especialmente a agropastoril, ocorre uma estruturação do espaço que resultaria no fechamento da fronteira, com a fixação dos Terena em certas parcelas de terras, e a sua transformação numa força de trabalho móvel dirigida pelo Estado. A antiga mobilidade espacial e a mistura étnica deram lugar ao estabelecimento de reservas indígenas, atribuindo-se a cada etnia um espaço limitado, o qual seria adequado, segundo os padrões da política do SPI, à nacionalização e à assimilação. 
João Pacheco de Oliveira Filho indicou como hipótese a existência de uma relação direta entre efetividade dos processos de demarcação de terras indígenas e atuação das frentes pioneiras ${ }_{1}{ }^{18}$ apontando que as terras indígenas foram demarcadas nas regiões em que as frentes de expansão primeiro atuaram. Poderíamos adicionar que, no caso do sul de Mato Grosso, a efetividade da demarcação caminhou passo a passo com o ritmo do fechamento da fronteira e com a necessidade de se definirem regionalmente as relações de propriedade e estruturação da organização socioespacial. No sul de Mato Grosso, as frentes de expansão condicionaram o fechamento da fronteira, e as demarcações das terras indígenas fizeram parte de uma estruturação do espaço que consolidava e institucionalizava uma configuração da ocupação espacial produzida pelo choque do colonialismo interno, ou seja, expressando a correlação de forças entre colonos e sociedades indígenas no final do século XIX e início do século XX. Assim, o fechamento da fronteira implicava necessariamente a demarcação de terras, não somente indígenas, mas do conjunto das terras do estado, e fazia parte de um movimento global de consolidação da estrutura agrária na fronteira.

Outro elemento importante é que antes do fechamento da fronteira existia uma tolerância em relação às terras indígenas, sendo garantido aos índios o uso da terra, mas sem nunca assegurar a plena regularização das mesmas (o que acontecia com a maioria das terras da fronteira, mesmo as não-indígenas). Embora existisse uma legislação que garantisse já no século XIX as posses aos indígenas das terras que ocupavam, estas garantias contrastavam com a configuração social da fronteira, que impunha - em razão da instabilidade da definição dos limites territoriais e do conflito característico do colonialismo interno - uma necessidade de que, no limite, o conflito de interesses fosse resolvido pela força material e simbólica, pela manipulação da estrutura jurídica e pelo uso sistemático da violência. A fronteira era necessariamente uma região de exceção, no sentido de que o colonialismo interno e o conflito de terras inerente a toda situação colonial jamais poderiam coexistir com uma aplicação isonômica da lei, uma vez que esta última não era um instrumento de mediação de interesses, mas veículo de expressão da contradição de interesses e dispositivo do poder hegemônico.

Assim, a visão de que os índios ocupavam espontaneamente e tão somente os territórios em que hoje estão localizados contrasta com os dados que mostram que o processo de fechamento da fronteira foi o que definiu sua localização e a formação de representações de que eles ocupavam somente as "aldeias", quando na realidade os próprios dados mostram o contrário além dos aldeamentos estatais, conhecidos e monitorados pelo Estado, exis- 
tiam núcleos indígenas de ocupação descentralizados em diversos pontos do território e aldeamentos oficiais hoje extintos. Mas na luta de classificações que hoje se dá nos processos judiciais, projeta-se no passado (no momento em que a fronteira ainda estava aberta no século XIX), como modelo de sociedade indígena, uma forma territorial e social que só passou a existir após o fechamento da fronteira no início do século XX: o modelo de que cada grupo étnico ocupava separadamente uma parcela de terras, reduzida e claramente delimitada, e que essas eram as terras indígenas. No entanto, essa imagem apenas apreende os efeitos territoriais da política adotada pelo Estado para os índios na fronteira no momento de seu fechamento.

O fechamento da fronteira produziu a estrutura agrária e, nela, o lugar das terras indígenas. Esse lugar foi estabelecido pela conjugação de dois fatores: a ação do Serviço de Proteção aos Índios (SPI) e as condições sociais específicas da fronteira. A ação do SPI ajudou na consolidação da estrutura agrária e, ao mesmo tempo, introduziu um tipo de política que operou diretamente sobre a identidade indígena. Assim, os conflitos judiciais em torno da demarcação das terras indígenas são uma consequência indireta das formas de incorporação das terras à estrutura agrária e ao tipo de política de Estado para as sociedades indígenas. As reivindicações de terras pelos índios Terena são, por sua vez, um questionamento da forma como esses espaços foram incorporados e distribuídos na estrutura agrária regional durante o período inicial de atuação das frentes de expansão.

Num certo sentido, no momento em que começa o processo de regularização fundiária que acompanha o fechamento da fronteira, quando essas terras foram incorporadas ao mercado, as terras indígenas são colocadas num patamar inferior de importância na hierarquia dos espaços, de maneira que não somente as regularizações foram realizadas a posteriori em relação aos títulos de propriedade (as terras indígenas terena começam a ser discriminadas em 1906 e, depois, a partir de 1920), como eram vistas apenas como um dispositivo a mais da política geral de assimilação dos índios e sua transformação em força de trabalho assalariada. Consolidando-se o fechamento da fronteira com uma estruturação e incorporação dos espaços ao sistema global, entrecruzam-se as questões relativas à administração de identidades e de territórios.

A região do Pantanal, por ser uma região de fronteira, era alvo de políticas indigenistas que visavam criar formas de nacionalização e assimilação dos índios, a partir de planos de mudança cultural que assegurassem a melhor vigilância da fronteira. Desta maneira, a localização de um grupo étnico numa região de fronteira internacional modificou a situação dos indígenas do sul de Mato Grosso, especialmente dos Terena, tornando-os alvos 
de políticas que incidiam ao mesmo tempo sobre territórios, identidades e populações. Emerge então o problema das identidades dos grupos indígenas, e a questão de como assimilar identidades étnicas específicas à identidade nacional. O problema da definição dos limites dos territórios indígenas dá lugar ao problema da definição dos limites da identidade indígena.

\section{Fronteira e identidades}

A consolidação das fronteiras nacionais e a delimitação das fronteiras internas entre terras públicas, terras indígenas e propriedades privadas em uma estrutura agrária foi um processo acompanhado também pela criação de representações legítimas acerca do lugar de cada um desses espaços dentro da sociedade e do imaginário social. A delimitação das terras indígenas igualmente implicou a atribuição de um lugar simbólico para os índios. Assim, eles ocupavam as terras reservadas pelo Estado, porque elas seriam as terras que efetivamente haviam ocupado antes, dado inferido da própria demarcação e esse espaço expressava também o lugar do devir dos índios, uma vez que eles ocupavam aquele espaço provisoriamente até completarem o processo de assimilação que estava sendo induzido pelo Estado nacional através do SPI. Como notaram Lima e Oliveira Filho, as reservas, centros agrícolas e outros dispositivos expressavam em termos administrativos a representação da condição transitória da indianidade (Lima 1995; Oliveira Filho 1999). Cria-se então um argumento cíclico: os índios estão em determinados espaços porque sempre estiveram neles e porque é onde deveriam estar.

As políticas do SPI foram, antes de tudo, políticas de nacionalização dos índios. As políticas para as aldeias e as reservas terena do sul de Mato Grosso visavam consolidar o espaço como um canal de assimilação, de transfiguração das identidades étnicas em uma identidade nacional homogênea. A fronteira foi assim, também, uma zona em que as fronteiras das identidades sociais eram objeto de conflitos e de políticas de disciplinarização. Essas políticas perduraram ao longo de toda a existência do SPI, e mesmo depois da criação da FUNAI, a ideia de que os Terena eram índios aculturados ou em vias de assimilação permaneceu em uso tanto no órgão indigenista, quanto difusa entre atores e instituições sociais:

O discurso da nacionalização continua, porém, assente sobre a ideia de grupos indígenas situados em estágios distintos da evolução humana, já que o decreto 5484, de 27/06/1928, responsável por uma categorização relativa ao grau de contato, cerne de ação protecionista, era ainda vigente. [...] Por exemplo, falando 
dos dois tipos de postos indígenas com os quais deveria contar o SPI à época, prevê para os Postos de Atração, Vigilância e Pacificação a tarefa de lidar com povos "imbeles, desarmados e na infância social, de modo a despertar-lhes o desejo de compartilhar conosco o progresso que atingimos". [...] O segundo tipo de posto, os de Assistência, Nacionalização e Educação, destinar-se-ia, de acordo com o Regulamento, a uma ou mais tribos em relações pacíficas e já sedentárias e capazes de se adaptarem à criação e à lavoura e a outras ocupações normais (Lima 1992:166).

A nacionalização era concebida como um processo pedagógico de educação e trabalho, e educação (técnica) para o trabalho. A partir da década de 1940, o organograma do SPI foi reestruturado para dar conta destas duas tarefas; seria incentivada a retomada da ideia do índio como guardião das fronteiras. Assim, os Postos Indígenas e as Inspetorias foram organizados para atuar de acordo com tais orientações gerais. Esta estrutura só sofreria propostas de alteração em $1960 .{ }^{19}$ Vejamos como era a distribuição dos PIs no sul de Mato Grosso:

\section{Quadro 5 - Postos Indígenas da IR-5 (sul de Mato Grosso e São Paulo)}

\begin{tabular}{|c|c|c|c|}
\hline $\begin{array}{c}\text { PIF } \\
\text { Postos } \\
\text { de Fronteira }\end{array}$ & $\begin{array}{c}\text { PIN } \\
\text { Postos de Assistência, } \\
\text { Educação e } \\
\text { Nacionalização }\end{array}$ & $\begin{array}{c}\text { PIC } \\
\text { Postos } \\
\text { de Criação }\end{array}$ & $\begin{array}{c}\text { PIA } \\
\text { Postos de } \\
\text { Alfabetização } \\
\text { e Tratamento }\end{array}$ \\
\hline $\begin{array}{c}\text { Vanuire } \\
\text { (Tupã/SP) }\end{array}$ & $\begin{array}{c}\text { Posto Curt } \\
\text { Nimuendajú (Ivaí/SP) }\end{array}$ & $\begin{array}{c}\text { Nabileque } \\
\text { (Ponta Porá/MT) }\end{array}$ & $\begin{array}{c}\text { Ipegue } \\
\text { (Aquidauana/MT) }\end{array}$ \\
\hline $\begin{array}{c}\text { Francisco Horta } \\
\text { (Dourados/MT) }\end{array}$ & $\begin{array}{c}\text { Posto Icatú } \\
\text { (Penápolis/SP) }\end{array}$ & & $\begin{array}{c}\text { Capitão Vitorino } \\
\text { (Nioaque/MT) }\end{array}$ \\
\hline $\begin{array}{c}\text { José Bonifácio } \\
\text { (Ponta Porá/MT) }\end{array}$ & $\begin{array}{c}\text { Posto Taunay } \\
\text { (Aquidauana/MT) }\end{array}$ & $\begin{array}{c}\text { Lalima } \\
\text { (Miranda/MT) }\end{array}$ \\
\hline $\begin{array}{c}\text { Benjamin Constant } \\
\text { (União/MT) }\end{array}$ & $\begin{array}{c}\text { Buriti } \\
\text { (Aquidauana/MT) }\end{array}$ & $\begin{array}{c}\text { São João do Aqui- } \\
\text { davão } \\
\text { (Miranda /MT) }\end{array}$ \\
\hline $\begin{array}{c}\text { Plvesidente } \\
\text { (Miranda/MT) }\end{array}$ & $\begin{array}{c}\text { Cachoeirinha } \\
\text { (Miranda/MT) }\end{array}$ & & \\
\hline
\end{tabular}


Os dados permitem ver que as tarefas da política indigenista no sul de Mato Grosso eram diferentes das do Norte, já que na IR-6 (norte de Mato Grosso), eram seis os PIs de atração (num total de 11) - enquanto no sul não existia nenhum destes - e cinco postos de nacionalização, dos quais a maioria era de índios Terena. Isto significa que nesse período o regime tutelar e a política indigenista foram veículos do processo de nacionalização, de construção e imposição de uma identidade nacional aos povos indígenas, resultando em que, simultaneamente ao impulso de preservar e garantir uma "aculturação paulatina", se tentava acelerar o processo de incorporação dos índios à nação como trabalhadores rurais. O antropólogo Altenfelder Silva registra assim a ação do SPI junto aos Terena de Bananal: ${ }^{20}$

Por iniciativa do Serviço de Proteção aos Índios foi restabelecida a "festa dos padres", o Oheokoti, celebrada agora no dia 19 de abril, Dia do Índio, juntamente com outras cerimônias cívicas brasílico-indígenas, tais como o hasteamento do Pavilhão Brasileiro, ao som do Hino Nacional entoado pelos índios, e a realização de danças terena, agora reavivadas (Altenfelder Silva 1949:359).

Mas as políticas de assimilação aplicadas aos índios das regiões de fronteira tiveram efeitos locais diversificados. No caso da sociedade Terena, os elementos das políticas nacionalistas foram incorporados ao universo ritual e mítico do grupo. A experiência dos índios na situação de fronteira e as questões políticas produzidas por tais experiências foram transcritas nas narrativas indígenas, de maneira que certos acontecimentos históricos ganham contornos míticos na interpretação indígena da sua própria história e da história da colonização.

O elemento fundamental é que os Terena apresentam hoje, sob a forma de mito e ritual, narrativas que, ao contrário de oporem sua identidade étnica à identidade nacional, mostram a sobreposição das duas identidades. As narrativas terena apontam, por exemplo, como personagem importante o índio Kaly Syny, que aparece nas narrativas de índios de Cachoeirinha e Limão Verde (sendo mencionado inclusive em livretos produzidos pelos indígenas) como o cacique e o koixomuneti (pajé) que teria conduzido a travessia dos índios terena pelo rio Paraguai e sido um personagem fundamental da Guerra. Kaly Syny teria tomado parte ativamente da organização dos Terena na Guerra do Paraguai e auxiliado as tropas brasileiras, com seus poderes de pajé, a derrotar os paraguaios em diversas batalhas.

Um rito que expressa essa narrativa é o hiokixoti-kipahe ("dança da ema" ou, como é mais conhecida, "dança do bate-pau"). A dança do bate-pau é um ritual praticado em todas as ocasiões consideradas importantes pelos 
Terena. As principais ocasiões em que ela acontece são no Dia do Índio e nas Festas de Santo realizadas em quase todas as comunidades indígenas. O Dia do Índio é emblemático, pois ele opera com uma duplicidade de rituais: os ritos nacionais/nacionalistas, como indicado por Altenfelder Silva, como o entoar do Hino Nacional e o hasteamento da bandeira, e os ritos indígenas, hoje em dia, especialmente a realização da dança do bate-pau. As questões colocadas pela articulação dos ritos são extremamente complexas, uma vez que mostram a apropriação dos símbolos nacionais, como a bandeira do Brasil, que é usada no rito pelos índios, que a seguram ou mesmo a acoplam às suas vestimentas de palha de bacuri ou de pena de ema, de maneira que é difícil separar a afirmação da identidade terena da identidade nacional.

Existem também diferentes interpretações acerca do significado e da origem da dança do bate-pau. De maneira geral, os Terena concordam que ela foi revelada a um pajé em sonhos, e que este a ensinou aos demais índios. Entretanto, duas versões distintas são narradas, apesar de ambas remeterem à guerra e à experiência social e histórica do grupo. Uma versão indica que a dança encena a guerra entre duas nações indígenas no Chaco ou Exiwa, e que ela é realizada para relembrar esta guerra e homenagear os mortos. Outra narrativa afirma que a dança do bate-pau foi revelada a um pajé após a Guerra do Paraguai para lembrar aos índios que eles tomaram parte nela para defender suas terras e, ao mesmo tempo, lembrar do sangue dos índios que fora derramado por isso. A dança é um ritual de memória dos combates e dos índios que neles tomaram parte e morreram.

A identidade dos índios terena, expressa sob a forma de ritual, articula a nacionalidade e a etnicidade. Ao contrário do que objetivavam as políticas de nacionalização do SPI e depois da FUNAI em relação à assimilação pela homogeneização cultural, os símbolos nacionais foram submetidos à interpretação local indígena, que inverteu a lógica de oposição entre identidade nacional e identidade étnica, criando uma identidade plural. De maneira simultânea, as narrativas que estão vinculadas ao ritual expressam um ponto de vista indígena sobre a sua experiência histórica na fronteira, ressaltando o elemento de conflito e a guerra que a caracterizam, criando um contradiscurso que enfatiza a importância dos Terena para a história nacional em razão da sua participação na Guerra do Paraguai (o que daria a legitimidade da sua reivindicação de terras, uma vez que eles tomaram parte nesta guerra para defender as suas e o território brasileiro).

Assim, a hipótese de que haja uma relação de exclusão necessária entre a identidade étnica e a identidade nacional, condicionada por uma suposta origem "externa" e a inexorabilidade da assimilação ou da primordialidade das identidades étnicas, contrasta com uma realidade sociocultural em que a identidade 
étnica específica dos Terena se articulou de forma inextricável com a identidade nacional, em parte pelas condições históricas peculiares da fronteira, em parte pelos processos de apropriação e estratégias do grupo. Desta forma, os índios produziram também um discurso, sob a forma de mito e ritual, que aborda a origem do grupo, articulando elementos históricos e mágico-religiosos, e que explica e justifica não somente sua presença nos territórios em que estão localizados, mas também a legitimidade da sua própria reivindicação de terras.

A identidade étnica e suas fronteiras não estão fechadas aos efeitos dos processos históricos e das políticas aplicadas nas regiões de fronteira econômica e política. Na realidade, a identidade étnica terena transformouse ao longo da história, vinculando-se à própria identidade nacional, de maneira que - não tendo ocorrido a assimilação dos índios no sentido da sua fusão ao conjunto da população com o desaparecimento da identidade étnica específica - houve uma articulação da identidade nacional com a identidade étnica. E este elemento torna ainda mais complexos os processos de luta de classificações nos processos judiciais.

Esta luta traz à tona outra pelo poder de criar representações legítimas acerca das identidades sociais e pela manutenção ou a transformação de aspectos de uma estrutura agrária. No caso da região do Pantanal no Mato Grosso do Sul e dos índios terena que a ocupam, pudemos ver que a fronteira condicionou o seu processo de territorialização e a definição de sua identidade. A experiência da ocupação de territórios na fronteira determinou sua localização espacial e a forma e o conteúdo da sua própria identidade étnica. Não são apenas os limites territoriais da fronteira que são móveis, mas também as fronteiras das próprias identidades sociais dos grupos nelas localizados, uma vez que tal localização implica a sujeição a diferentes tipos de políticas, tanto simbólicas quando econômicas, que condicionam o desenvolvimento dos grupos sociais e dos territórios e dão a sua especificidade.

As identidades étnicas e nacionais, bem como as fronteiras, são reelaboradas em função das relações de força; são essencialmente móveis, no tempo e no espaço, o que torna ainda mais complexas as questões colocadas nos conflitos decorrentes dos processos de identificação e demarcação de terras indígenas. Os processos judiciais e as estratégias político-jurídicas adotadas contra a demarcação das terras indígenas visam impor certas representações como legítimas. Entretanto, ao analisarmos a história e a evolução da fronteira, vemos que nem os territórios nem os grupos sociais estavam, há um século atrás, encapsulados dentro dos limites em que hoje se encontram, e que também eles e suas identidades não permaneceram estáticos no tempo, mas foram deslocados, recortados, reagrupados e reformulados por lutas políticas, guerras, processos de colonização e atuação das 
frentes de expansão. É possível constatar que as representações contidas nos discursos dos atores no conflito devem ser consideradas como parte da realidade da luta de classificações, e não como chave para a compreensão da realidade tal como classificada e representada por eles.

Recebido em 28 de outubro de 2008

Aprovado em 22 de setembro de 2009

Andrey Cordeiro Ferreira é doutor em antropologia social pelo PPGAS/MN/UFRJ e professor de sociologia. E-mail: <andrey2099@yahoo.com.br>

\section{Notas}

${ }^{*}$ Este trabalho foi elaborado a partir da releitura de certos dados contidos em minha tese de doutoramento, Tutela e Resistência Indígena (Museu Nacional, 2007), e da reflexão acerca de minha atuação como perito judicial num processo referente aos índios de Limão Verde, Mato Grosso do Sul.

${ }^{1}$ Um grupo de indígenas de Cachoeirinha ocupou a Fazenda Santa Vitória, que está dentro dos territórios identificados pelo GT da FUNAI.

${ }^{2}$ Outra parte da estratégia político-jurídica busca amparo na Súmula 650 do STF que trata dos aldeamentos extintos. Assim, ao mesmo tempo, afirma-se que a ocupação não é imemorial e que, se ocorreu, foi interrompida voluntariamente, caracterizando a extinção de aldeamentos.

${ }^{3}$ A noção de colonialismo interno está originalmente ligada a fenômenos de conquista, em que as populações de nativos não são exterminadas e fazem parte, em primeiro lugar, do Estado colonizador, e depois do Estado que adquire uma independência formal, ou que inicia um processo de libertação. Os povos, minorias ou nações colonizadas pelo Estado nacional sofrem condições semelhantes às que os caracterizam no colonialismo e no neocolonialismo em nível internacional (Casanova 2007).

${ }^{4} \mathrm{O}$ topônimo Chaco (do Qêchua, Chacu) indicava inicialmente a província de Tucumán, passando a designar posteriormente todo o território a leste dela, numa extensão de 700 mil quilômetros, abrangendo territórios da Bolívia, Argentina, Paraguai e Brasil (Carvalho 2002:457). 
5 "Os Terena buscavam suas vantagens na província de Xerez na outra orla do Rio Paraguai, especialmente quando se fundaram as reduções entre os Itatim-Guaranis de Caaguasú e Tare. Suas relações com os Guaranis das reduções e, ao que parece, também com os Itatins livres, se baseavam em periódicas relações de troca, a única maneira possível de adquirir ferro em troca das mantas Chanés, de algodão" (Susnik 1978:113).

6 “Os Guaicurus e os Guanás são duas grandes nações que anteriormente à vinda dos portugueses se haviam apoderado das margens do Mondego, travando guerra com os Guaxis, seus primitivos habitantes" (Castelnau 2000:403). O Mondego a que se refere Castelnau é o rio Miranda, como ele explica em seu livro.

${ }^{7}$ Existe um mapa no Arquivo Nacional, do Serviço do Estado Maior do Exército, que apresenta os locais das ocupações espanholas e os aldeamentos no sul de Mato Grosso.

${ }^{8}$ Segundo um relatório: "No districto do Baixo Paraguay, diversas tribus, particularmente das nações Guaná e Guaicurú, existem aldeadas com hum tal qual principio de civilização, e entretem connosco relações mais ou menos estreitas" (Capitão de Fragata Augusto Leverger, Relatório 1851, pp. 44-45). O processo de catequese e civilização dos Quiniquinau teria sido iniciado, então, em 1831.

${ }^{9}$ Existia no Mato Grosso uma política de incentivo à imigração de europeus, como forma de colonizar a região, resolver o problema de mão-de-obra e garantir o desenvolvimento econômico (ver Relatório da Província de Mato Grosso 1862, pp. 39-40).

${ }^{10} \mathrm{O}$ relatório menciona a concessão de 266 lotes para a construção de casas em Corumbá. População: 1.187 brasileiros (316 oficiais e praças); 84 estrangeiros (franceses, espanhóis, italianos, alemães, argentinos, corrientinos, orientais, bolivianos, americanos); 44 escravos.

${ }^{11}$ Caetano Pinto de Miranda e Ricardo de Almeida Serra se colocam nesses termos em alguns de seus relatórios.

${ }^{12}$ Esta argumentação consta em quase todos os Relatórios de Presidente de Província.

${ }^{13}$ O Governo Imperial deu alguns incentivos ao comércio da região: 1. reabertura da alfândega em Corumbá; 2. isenção de impostos para as mercadorias que circulassem naquele Porto. Assim se estabeleceram as bases para uma retomada econômica através da abertura comercial.

${ }^{14}$ A cidade de Aquidauana, por exemplo, foi fundada por um conjunto de Coronéis, que exerceram grande influência na política local.

15 "Na mensagem apresentada à Assembleia Legislativa, no dia 13 de maio de 1924, o Presidente de Matogrosso, Pedro Celestino Corrêa da Costa, dizia que 
enquanto a receita do Estado orçava em cinco mil contos, a da empresa do mate sozinha conseguia trinta mil contos, chegando o Estado a emprestar dinheiro dessa empresa" (Borges 2001:59).

16 "Hum so ramo de riqueza, de alguma importancia cai tomando incremento; he a criação de gado, em parte deste Município e do Poconé. Reduzida a nossa exportação a quase nenhum ouro, poucos diamantes, diminuta quantidades de couro e poaia e algum gado para as Províncias de Minas e de S.Paulo, o commercio alimenta-se quasi exclusivamente, com avultadas quantias que annualmente sahem do Thesouro Nacional..." (Relatório de Presidente de Província 1851:14).

${ }^{17} \mathrm{O}$ relatório indica ainda que existia em processo de regularização o seguinte número de posses: anteriores a 1854, 1.333 estabelecimentos; anteriores a 1889, 1.393 estabelecimentos; sem data, 297 estabelecimentos. Destas, apenas 452 haviam sido medidas e demarcadas. "Dessas 3029 posses registradas somente 1941 teem declarada a área ocupada, com a superfície de 13.753.011 hectares. Si arbitrarmos para as 1082 restantes, quase todas anteriores a 1854, a média de 13068 hectares, teremos para a sua superfície 14.139.576 hectares" (:20). A área total das posses era de 27.892.587 hectares e a área total do Mato Grosso, de 218.562.300 hectares.

18 "Por ora basta reter a hipótese de uma correlação entre avanço das frentes pioneiras (e consequentemente incorporação dessa região à economia de mercado) e efetividade no processo de demarcação das terras indígenas" (Oliveira Filho 1998:29).

${ }^{19}$ De acordo com um plano de acordo de reorganização do SPI (ver Lima, 1995).

${ }^{20}$ É interessante ver que, apesar de tais ritos serem sistematicamente registrados desde os anos 1920, fala-se aqui em "reavivamento".

\section{Referências bibliográficas}

ANDERSON, Benedict. 1989. Nação e consciência nacional. Rio de Janeiro: Editora Ática.

AZANHA, Gilberto. 2001. Relatório de identificação das terras indígenas Cachoeirinha, Buriti e Taunay-Ipegue. Centro de Trabalho Indigenista. http://www.trabalhoindigenista. org.br

BACH, J. 1916. Dados sobre los Índios
Terenas de Miranda. Anales de la Sociedad Científica Argentina. Buenos Aires. pp.. 87-94.

BAINES, Stephen G. 1993. "A política indigenista governamental e os WaimiriAtroari: administrações indigenistas, mineração de estanho e a construção da autodeterminação indígena dirigida". Revista de Antropologia, 36:207-237. 
BALANDIER, Georges. 1993. "A noção de situação colonial". Cadernos de Campo, 3:107-131. 1969. Antropologia política. Barcelona: Ediciones Península.

BARTH, Fredrik. 1996. "Economic spheres in Darfur". In: F. Raymond (org), Themes in economic anthropology. Londres: Tavistock. pp. 149-174.

- 2000a. "Os grupos étnicos e suas fronteiras". In: Tomke Lask (org.), O guru, o iniciador e outras variações antropológicas. Rio de Janeiro: Contra Capa. pp. 25-67.

. 2000b. "A análise da cultura nas sociedades complexas". In: Tomke Lask (org.), O guru, o iniciador e outras variações antropológicas. Rio de Janeiro: Contra Capa. pp.107-140. . 2000c. "Por um maior naturalismo na conceitualização das sociedades". In: Tomke Lask (org.), O guru, o iniciador e outras variações antropológicas. Rio de Janeiro: Contra Capa. pp. 167-186.

BATALHA, Guillermo Bonfil. 1972. “El concepto de índio en América: una categoria de la situacíon colonial". Anales de Antropologia, IX:105124.

- 1979. Indianidad y descolonización en América Latina. México: Editorial Nueva Imagen.

BECKER, Berta. 1990. "A fronteira em fins do século XX: oito proposições para um debate sobre a Amazônia". In: __ et al. Fronteira Amazônica: questões sobre a gestão do território. Brasília/ Rio de Janeiro: Editora UnB e Editora UFRJ. pp. 15-25.

BORGES, Fernando Tadeu de Miranda. 2001. Do extrativismo à pecuária: algumas observações sobre a história econômica de Mato Grosso. 1870 a 1930. São Paulo: Scortecci Editora. BOURDIEU, Pierre. 1990. Coisas ditas. São Paulo: Editora Brasiliense.
- 1989. O poder simbólico. Rio de Janeiro: DIFEL.

CAMPESTRINI, Hildebrando \& GUIMARÃES, Acir Vaz. 2002. História de Mato Grosso do Sul. Mato Grosso do Sul: IHGB.

CARDOSO DE OLIVEIRA, Roberto. 1976. Do Índio ao Bugre: o processo de assimilação dos Terena. Rio de Janeiro: Editora Francisco Alves.

2002. O diário e suas margens: viagem aos territórios Terena e Tukuna. Brasília: Editora UnB.

- 1968. Urbanização e tribalismo: integração dos índios Terena numa sociedade de classes. Rio de Janeiro: Zahar Editores.

CARVALHO, Edgard de Assis \& JUNQUEIRA, Carmen. 1981. Antropologia e indigenismo na América Latina. São Paulo: Cortez.

CARVAlHO, Silvia M. S. 2002. "Chaco: encruzilhada de povos e 'melting pot' cultural, suas relações com a bacia do Paraná e o sul mato-grossense". In: Manuela Carneiro da Cunha (org.), História dos índios no Brasil. São Paulo: Companhia das Letras. pp. 457-474.

CASANOVA, Pablo González. 2002. Exploração, colonialismo e luta pela democracia na América Latina. Petrópolis: Vozes.

. 2007. "Colonialismo interno (uma redefinição)". In: A. A. Boron; J. Amadeo \& S. Gonzalez (orgs), A teoria marxista hoje. Problemas e perspectivas. http:// bibliotecavirtual.clacso.org.ar/ar/libros/campus/marxispt/cap. 19.doc

CASTELNAU, Francis. 2002. Expedição às Regiões Centrais da América do Sul. Belo Horizonte: Editora Itatiaia.

CENSO da População dos Índios Desaldeados em Campo Grande/MS 1999. 2000. Campo Grande: UCDB, CIMI, PMCG e Arquidiocese de Campo Grande-Pastoral do Índio. 84p. 
CLIFFORD, James. 1994. "Diásporas". Cultural Anthropology, 9(3):302-338.

COSTA, Maria de Fátima. 1999. História de um país inexistente: o Pantanal entre os séculos XVI e XVIII. São Paulo: Editora Estação Liberdade e Livraria Kosmos Editora.

CUNHA, Manuela Carneiro da. 1987. Os direitos do índio: ensaios e documentos. São Paulo: Editora Brasiliense. - (org.). 1992. História dos índios no Brasil. São Paulo: Companhia das Letras.

FERREIRA, Andrey Cordeiro. 2002. Mudança cultural e afirmação identitária: a antropologia, os Terena e o debate sobre aculturação. Dissertação de Mestrado, Universidade Federal do Rio de Janeiro, MN-PPGAS. xii, 117p. il.

FOUCAULT, Michel. 1997. A arqueologia do saber. Rio de Janeiro: Editora Forense Universitária.. . 1999. Em defesa da sociedade. São Paulo: Martins Fontes.

FREIRE, Carlos Augusto da Rocha. 1990. Indigenismo e antropologia: o Conselho Nacional de Proteção aos Índios na Gestão Rondon (1939-1955). Dissertação de Mestrado, Programa de PósGraduação em Antropologia Social, Museu Nacional/UFRJ. 379p.

KUPER, Adam. 1992. Conceptualizing society. London: Routledge. 1999. Culture: the anthropologist's account. Cambridge/Massachusetts/ London, England: Harvard University Press.

LENA, Philippe \& OLIVEIRA, Adélia Engrácia de. 1991. Amazônia: a fronteira agrícola vinte anos depois. Belém: Museu Paraense Emilio Goeldi.

LIMA, Antonio Carlos de Souza. 1995. Um grande cerco de paz: poder tutelar, indianidade e formação do Estado no Brasil. Petrópolis/RJ: Editora Vozes. - 1998. "Os relatórios antropológicos de identificação de terras indígenas da Fundação Nacional do Índio. Notas sobre o estudo da relação entre indigenismo e antropologia no Brasil, 19681985". In: João Pacheco de Oliveira Filho (org.), Indigenismo e territorialização: poderes, rotinas e saberes coloniais no Brasil contemporâneo. Rio de Janeiro: Contra Capa. pp. 221-268.

- 1992. "O governo dos índios sob a gestão do SPI". In: Manuela Carneiro da Cunha (org.), História dos índios no Brasil. São Paulo: Companhia das Letras. pp. 155-172.

METRAUX, Alfred. 1946. "Ethnography of The Chaco". In: J. Steward (org.), Handbook of south american indians, volume 1. Washington: United States Government Printing Office. pp. 197370.

MOREIRA NETO, Carlos de Araújo. 1971. A política indigenista brasileira $d u-$ rante o século XIX. São Paulo: Faculdade de Filosofia, Ciências e Letras de Rio Claro.

OBERG, Kalervo. 1948. The Terena and the Caduveo of southern Mato Grosso, Brazil. Washington D.C: Department of State, US Government Printing Office/ Smithsonian Institution Institution/Institute of Social Anthropolgy, Publication $\mathrm{N}^{\circ}$. 9. 74 p.

OLIVEIRA FILHO, João Pacheco de. 1999. Ensaios em antropologia histórica. Rio de Janeiro: Editora da UFRJ. · 1986. "Antropologia política". In: Dicionário brasileiro de ciências sociais. 1.ed. Rio de Janeiro: FGV/MEC. pp. 64-67.

. (org.). 2006. Hacia una antropologia del indigenismo. Rio de Janeiro: Contra Capa.

- (org.). 1998. Indigenismo e territorialização: poderes, rotinas e saberes coloniais no Brasil contemporâneo. Rio de Janeiro: Contra Capa. - 1988. O nosso governo: os Ticuna e o regime tutelar. Rio de Janeiro: Editora Marco Zero. 
SILVA, Fernando Altenfelder. 1949. "Mudança cultural dos Terena". Revista do Museu Paulista, III:271-379.

SUSNIK, Branislava. 1978. Los aborígenes del Paraguay: etnología del Chaco Boreal y su periferia (siglos XVI e XVII). Assuncion: Museo Etnográfico Andrés Barbero.

· 1981. Los aborígenes del Paraguay: etnohistoria de los chaqueños (16501910). Assuncion: Museo Etnográfico Andrés Barbero.

VARGAS, Vera Lúcia Ferreira. 2003. A construção do território terena (1870-1966): uma sociedade entre a imposição e a opção. Dissertação de Mestrado em História. UFMS, Dourados. Ms. 161p.

VASCONCELOS, Cláudio Alves de. 1999. A questão indígena na província de Mato Grosso: conflito, trama e continuidade. Campo Grande: Editora UFMS.

VELHO, Otávio Guilherme. 1979. Capitalismo autoritário e campesinato. Rio de Janeiro: DIFEL.

. 1972. Frentes de expansão e estrutura agrária. Rio de Janeiro: Zahar Editores.

\section{Relatórios dos Presidentes de Província}

(in Center for Research Libraries: http:// www.crl.edu/content)

Relatório de 1837. José Antonio Pimenta Bueno, 01/03/1838

Relatório de 1838. José Antonio Pimenta Bueno, 01/03/1838

Relatório de 1840. Estevão Ribeiro de Rezende

Relatório de 1849, 3 de Maio. Pelo Major Doutor João de Oliveira.

Relatório de 1851, 10 de Maio de 1851. Pelo Capitão de Fragata Augusto Leverger

Relatório de 1857. Albano de Souza Osório.
Relatório de 1858. Albano de Souza Osório.

Relatório de 1859. Joaquim Raimundo de Lamare

Relatório de 1862. Herculano Ferreira Penna

Relatório de 1863. Herculano Ferreira Penna

Relatório de 1864. Alexandre Manoel Albino de Carvalho

Relatório de 1865, 17 de outubro. Augusto Leverger

Relatório de 1869. 20 de Setembro. Barão de Melgaço.

Relatório de 1872. Cardozo Junior

Relatório de 1877. 03/05/1877. General Hermes Ernesto da Fonseca

Relatório de 1879. 05/12. João José Pedrosa.

Relatório de 1893.

Relatório de 1895. 


\section{Resumo}

Este artigo analisa a problemática da fronteira a partir do estudo da situação dos índios Terena no Mato Grosso do Sul, localizados em aldeias de uma região de fronteira internacional. Pretendemos apresentar algumas reflexões teóricas sobre essas lutas simbólicas e também o processo de desenvolvimento da fronteira e seus efeitos sobre as sociedades indígenas. Pretendemos realizar dois movimentos analíticos: 1. a análise da luta simbólica que perpassa os processos judiciais desencadeados por conflitos territoriais entre os índios Terena e os produtores rurais, mostrando como a ideia de fronteira é ativada na construção de mecanismos políticos de exclusão e (des)legitimação de grupos étnicos; 2. a análise das políticas de Estado para a fronteira, as dinâmicas territoriais e sua confrontação com as políticas simbólicas indígenas nas diferentes situações locais na fronteira, que igualmente integram a luta simbólica por identidades reconhecidas como legítimas e territórios.

Palavras-chave Fronteira, Identidade, Índios Terena

\section{Abstract}

This article analyzes the issue of the border based on a study of the experiences of the Terena indigenous people in Mato Grosso do Sul, living in villages situated in an international border region. I present a number of theoretical reflections on these symbolic conflicts, the border development process and its effects on indigenous societies. The article contains two analytic movements: 1. an analysis of the symbolic conflict permeating the legal processes linked to the territorial conflicts between the Terena and rural producers, showing how the idea of the border is activated in the construction of political mechanisms for excluding and (de)legitimizing ethnic groups; 2 . an analysis of the State's border policies, the territorial dynamics and its confrontation with the indigenous symbolic policies in the different local situations on the border, which also form part of the symbolic fight for recognition of the legitimacy of indigenous identities and territories.

Key words Border, Identity, Terena 